\title{
Seed nutrient content and nutritional status of Posidonia oceanica seedlings in the northwestern Mediterranean Sea
}

\author{
Elena Balestri ${ }^{1, *}$, Sylvie Gobert ${ }^{2}$, Gilles Lepoint ${ }^{2}$, Claudio Lardicci $^{1}$ \\ ${ }^{1}$ Dipartimento di Biologia, University of Pisa, Via Derna 1, 56100 Pisa, Italy \\ ${ }^{2}$ MARE centre, Laboratoire d'Océanologie, Institut de Chimie, University of Liège, Bât B6c, 4000 Liège, Belgium
}

\begin{abstract}
We studied nutritional constraints on growth of Posidonia oceanica seedlings, morphometry and elemental content of mature seeds, and seedlings stranded on a beach of the northwestern Mediterranean Sea on 3 dates (May 2004, May 2005 and December 2005). The mean total nitrogen $(\mathrm{N})$ and phosphorus (P) content of $P$. oceanica seeds was high compared with closely related species. Seeds varied considerably in mass, and their nutrient and carbon (C) content increased linearly with mass. This indicates substantial variation in the amount of reserves initially available for seedling growth. Stored reserves in seeds were used by seedlings within 6 to 8 mo after germination: $\mathrm{P}$ was retrieved with greater efficiency $(86 \%)$ than was N (69\%) and C $(20 \%)$. From May to December of the 2nd year (2005), the tissue nutrient concentrations of seedlings declined due to fast utilization and translocation of nutrients from the internal pools to support summer growth. Instead the C concentration in roots and rhizomes increased, indicating an accumulation of C. Seedling tissue N and P concentrations were above the critical levels reported for seagrasses, and were also lower than those of plagiotropic rhizomes of $P$. oceanica collected in the same period. These results suggest that $\mathrm{P}$ may play a major role in constraining growth of $P$. oceanica seedlings.
\end{abstract}

KEY WORDS: Seeds · Seedlings · Nutritional constraints · Morphometric analysis · Elemental analysis

\section{INTRODUCTION}

Seagrasses can reproduce both vegetatively by ramets and sexually by seeds. In some species, however, sexual recruitment is severely constrained by depressed seedling growth and survival (Hootsmans et al. 1987, Duarte \& Sand-Jensen 1990, Terrados 1993, Olesen \& Sand-Jensen 1994, Balestri et al. 1998a). One of the major factors likely to reduce seedling survival is the incapacity of seedlings to acquire sufficient nutrients to support continued growth in environments where nutrients are scarce or patchily distributed. However, attempts to assess the importance of nutrients in constraining seedling growth for seagrasses have been few (Robertson \& Mann 1984, Duarte \& Sand-Jensen 1996, Nielsen \& Pedersen 2000, Walker et al. 2004). Duarte \& Sand-Jensen (1996) have found that $\mathrm{P}$ limitation may be the major cause of failure of seedlings to develop new patches in the Mediterranean seagrass Cymodocea nodosa (Ucria) Aschers. On this basis, the authors supposed that severe nutrient deficiency is also the reason for the low reproductive success of Posidonia oceanica (L.) Delile, the endemic and dominant seagrass species in the Mediterranean Sea.

This slow growing species forms large meadows in oligotrophic areas subjected to seasonal variation of nutrients, i.e. relatively high concentrations of $\mathrm{N}$ and $\mathrm{P}$ in late autumn-winter and low concentrations in spring-summer (Ballesteros 1989, Alcoverro et al. 1995, 1997, Vidondo \& Duarte 1995). Nutrient limitation in mature stands may be high from May to 
October, and may involve both $\mathrm{N}$ and $\mathrm{P}$ (Alcoverro et al. 1997). To compensate for seasonal nutrient limitation the plant has evolved a complex strategy of nutrient conservation and recycling (Alcoverro et al. 1995, 1997, 2000, 2001, Invers et al. 2002, Lepoint et al. 2002). Flowering and fruit production is highly variable in space and in time, with intensive synchronized flowering episodes occurring at 8 to $10 \mathrm{yr}$ intervals (Balestri \& Cinelli 2003, Balestri 2004, Diaz-Almela et al. 2006). At maturity (early spring) the positively buoyant fruits are transported by currents away from parental shoots, enabling dehisced seeds to colonize sites outside the range of vegetative growth (Buia \& Mazzella 1991, Balestri et al. 2006). Recruitment by seeds has been observed only occasionally in the field (Buia \& Mazzella 1991, Balestri et al. 1998b, Piazzi et al. 1999, Diaz Almela et al. 2008). Although densities as high as to 480 germinated seeds $\mathrm{m}^{-2}$ have been detected in favorable sites, available data indicate that only a few seedlings can initiate new patches (Balestri et al. 1998b, Alberto et al. 2003, Jover et al. 2003, Migliaccio et al. 2005, Balestri \& Lardicci 2008, Diaz Almela et al. 2008). It seems that newly established seedlings rely on seed C-based reserves for most of the 1st year (Balestri et al. 1998b, Belzunce et al. 2005), but subsequently a large proportion of them (ca. $70 \%$ ) perish possibly due to environmental stresses (Balestri et al. 1998a, Piazzi et al. 1999, Balestri \& Bertini 2003, Balestri \& Lardicci 2008). Virtually nothing is known, however, on seed nutritional quality and nutritional status of seedlings during early growth.

In nutrient-poor habitats, the ability of seedlings to become established and cope with environmental stressors (i.e. nutrients, defoliation, herbivores and pathogens) depends, in large part, by the amount of reserves originally available to the seedlings (Foster 1986, Mazer 1989, Houssard \& Escarré 1991, Seiwa \& Kikuzawa 1991, Milberg \& Lamont 1997, Bonfil 1998, Tyler \& Zohlen 1998, Naegle et al. 2005). A number of studies have demonstrated that seed mass is a major determinant of seed reserves, and substantial seed mass variation exists at many scales (i.e. among populations and plants and within plants) in a range of terrestrial species (Ågren 1989, Matthies 1990, Mehlman 1993, Obeso 1993, Lord 1994, McKee \& Richards 1996, Navarro 1996, Krannitz 1997, Vaughton \& Ramsey 1998, Simons \& Johnston 2000) because of reduced resource availability throughout the growing season, or architectural or physiological constraints operating during seed provisioning (Susko \& Lovett-Doust 2000, Vaughton \& Ramsey 2001). Differences in seed mass may affect seedling recruitment via effects on seedling growth and survivorship. Generally, under nutrientlimited conditions, seedlings from small seeds have low ability to sustain normal seedling growth, whereas those from large seeds have energy and nutrients necessary for maximizing initial growth and are able to recover from stress (Vaughton \& Ramsey 1998, Susko \& Lovett-Doust 2000, Vaughton \& Ramsey 2001). Therefore, information on the degree of variation in seed quality may be important when assessing the causes for reducing recruitment success and the capacity of seedlings of Posidonia oceanica to cope with nutrient stress.

After the latest important flowering of Posidonia oceanica recorded in the Mediterranean Sea (Balestri 2004, Diaz-Almela et al. 2006), a large number of fruits and seedlings detached from a meadow off the coast of northwestern Italy after storms and were deposited on a beach on 3 different dates. This reproductive material offered an opportunity to (1) determine the degree of variation in seed mass and the influence of seed mass on the seed reserve ( $C, N$ and $P$ ) content and (2) evaluate which putative elements might be limiting to growth in seedlings. To achieve these goals, we examined the changes in $\mathrm{C}, \mathrm{N}$ and $\mathrm{P}$ concentrations (and their atomic ratios) in the different components of seedlings (seed remains, leaves, leaf scars, roots and rhizomes) over the sampling events. The $\mathrm{C}$ and nutrient concentrations in the different tissues of seedlings and adult shoots were also compared.

\section{MATERIALS AND METHODS}

Plant material and processing. Fruits of Posidonia oceanica were collected in May 2004, while seedlings and rhizome fragments were collected in May 2005 and December 2005 (Table 1) on a beach of Tuscany (Italy, Ligurian Sea, northwestern Mediterranean; $43^{\circ} 37^{\prime} \mathrm{N}, 10^{\circ} 20^{\prime} \mathrm{E}$ ). On the basis of available data on waves and wind direction (National Wavemetric Net, Istituto Superiore per la protezione e la ricerca ambientale, available at www.idromare.it), the fruits have been assumed to come from a large $P$. oceanica meadow located offshore (Meloria Shoals). The seedlings had sediment particles still attached to roots; they were evidently established in some unknown

Table 1. Posidonia oceanica. Type of material examined, sampling date and sample size

\begin{tabular}{|lcr|}
\hline Plant material & Date & Size \\
\hline Mature fruits & 7 May 2004 & 30 \\
Live seedlings (1 yr) & 10 May 2005 & 38 \\
Dead seedlings & 10 May 2005 & 34 \\
Live seedlings (1-2 yr) & 4 Dec 2005 & 14 \\
Plagiotropic rhizomes & 4 Dec 2005 & 3 \\
\hline
\end{tabular}


area close to the meadow in May to June 2004 and then dislodged from the substrate by storms. Water column nutrient concentrations at the site were low and corresponded to oligotrophic conditions as reported by Sistema Difesa Mare (Si.Di.Mar. 2005). As seeds are likely to germinate within a few days after fruit dehiscence (Balestri et al. 1998b), the seedlings collected in May 2005 were about 12 mo old at the time of collection (1 yr seedlings) and those of December were about 19 mo old (1 to 2 yr seedlings). Many seedlings collected in May did not show standing leaves and were thus categorized as dead seedlings.

In the laboratory, seeds were extracted from dehiscent fruits (Fig. 1A). To examine natural variation in seed mass, mature seeds (i.e. seeds with a developed plumule) were individually weighed after oven-drying at $70^{\circ} \mathrm{C}$ for $48 \mathrm{~h}(\mathrm{n}=30)$. Seeds determined to be aborted or damaged were discarded. To examine seedling development, morphological measurements (number of standing leaves, length of the longest leaf, number of leaf scars, number of shoots, length of rhizome, number of roots and length of longest root) were carried out on a subsample $(n=6)$ of live seedlings in each sampling event. The total number of leaves produced during the shoot's life span of a seedling was estimated as the sum of the number of leaf scars and the number of standing leaves. The number of leaves produced by seedlings collected in May 2005 (i.e. at the end of their 1st year) corresponded to the annual leaf production rate of seedlings. This value was used to estimate the average monthly leaf formation rate of seedlings. The morphological characteristics of dead seedlings were also examined and compared with those of live seedlings collected in the same period $(\mathrm{n}=$ 10). The number of leaves that had been produced by dead seedlings was derived from the number of leaf scars present along the rhizomes. The remaining seedlings were partitioned into their tissue compo-
A) Seed in a dehisced fruit

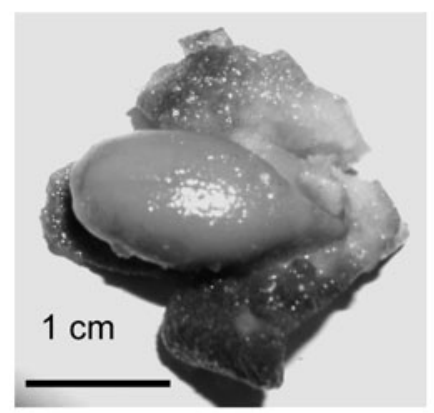

C) Dead seedling

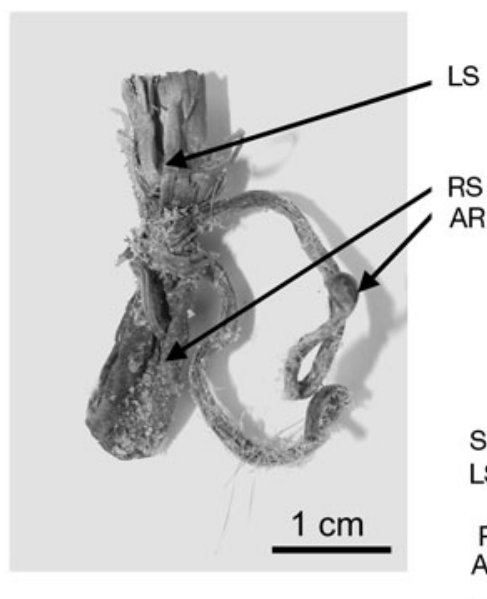

B) Live seedling

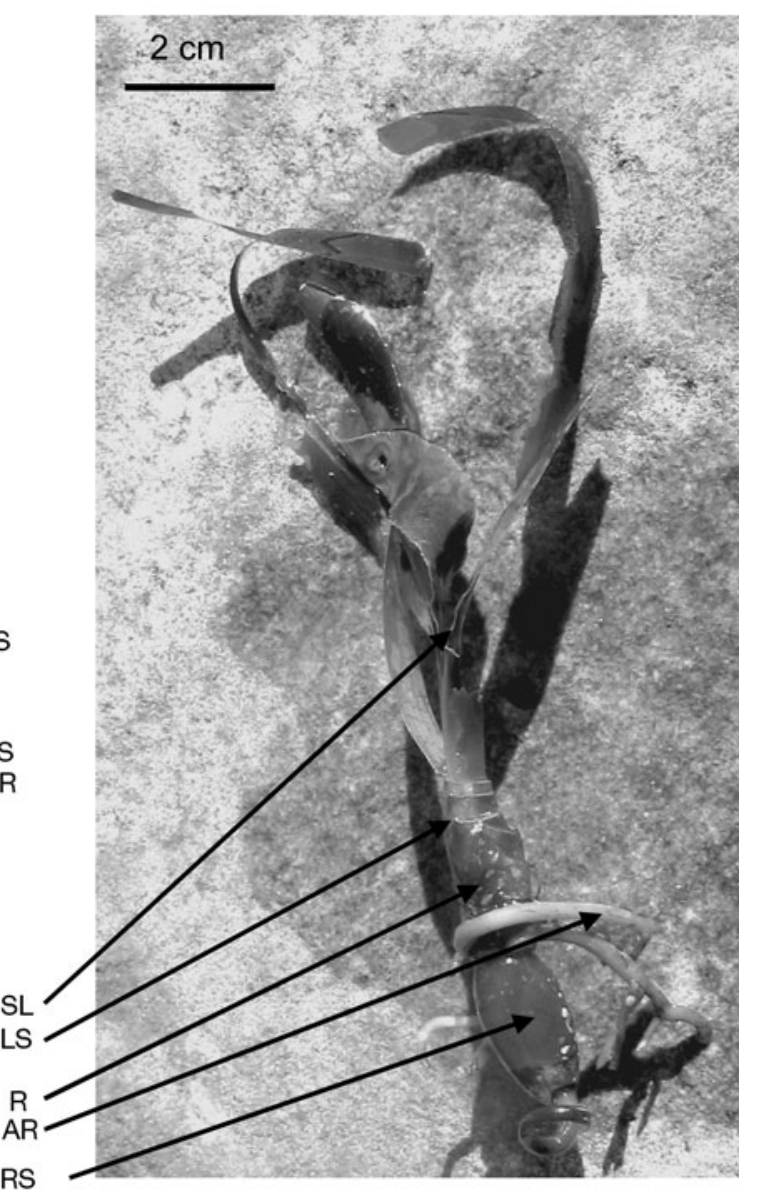

Fig. 1. Posidonia oceanica. (A) Mature seed in a dehisced fruit, (B) live seedling and (C) dead seedling. Arrows shows the tissue components of seedlings used in the elemental analysis. AR: adventitious roots; SL: standing leaves; LS: leaf scars; R: rhizome; 
nents (leaves, leaf scars, rhizome, root and remains of seed if present) (Fig. 1B,C) to examine the nutritional status and the potential role of each tissue component in the seedling nutrient economy. Seedlings with signs of herbivore damage were discarded. Finally, to compare the nutrient concentrations of seedlings and adult shoots, 3 plagiotropic fragments with the apical shoot and 2 to 3 lateral shoots were selected and then cut into segments that were separated into tissue components.

Elemental analysis. Mature seeds, and the seedling and shoot biomass fractions were dried at $70^{\circ} \mathrm{C}$ and placed under a glass bell with fuming $\mathrm{HCl}$ (37\% analytical grade, Merck) for $24 \mathrm{~h}$ to remove all traces of calcareous epiphytes, and then ground into a homogeneous powder (MM 301 microgrinding device, Retch). Elemental analyses of $\mathrm{C}$ and $\mathrm{N}$ were performed on dry samples (2 to $6 \mathrm{mg}$ ) using a C:N:S analyser (NA 1200, Carlo Erba). Elemental analysis of $\mathrm{P}$ was performed using an inductively coupled plasma-mass spectrometer (Elan DCR II) on a 10 mg distilled water (DW) sample after digestion with $\mathrm{HNO}_{3}$ and $\mathrm{H}_{2} \mathrm{O}_{2}$ in an Ethos D microwave digester. Total reserves of seeds $(C, N$ or $P$, $\mathrm{mg} \mathrm{seed}^{-1}$ ) in fruits were calculated from the mass (mg dry weight [dry wt]) of each seed multiplied by the relative C, N or P concentration (\% dry wt). Since a single seedling did not provide adequate tissue material for elemental analysis, the material from the corresponding tissue fractions of 2 or 3 seedlings was combined into a single sample.

Data analysis. To examine variation in seed mass the coefficient of variation $(\mathrm{CV}=100 \times \mathrm{SD} /$ mean) for seed dry mass was calculated. The influence of seed mass on seed $\mathrm{C}, \mathrm{N}$ or $\mathrm{P}$ content $\left(\mathrm{mg} \mathrm{seed}^{-1}\right.$ ) was examined by least-squares linear regression analyses on log-transformed variables. Multivariate analysis of variance (MANOVA) was used to test for differences in the growth characteristics of live seedlings between the sampling events (May versus December). The significance of multivariate main effects was determined from Wilks' A statistics. When MANOVA indicated significant differences between events, univariate ANOVAs were run on each of the response variables examined. The benefit of using multivariate analyses was protection against Type I error resulting from multiple tests of correlated variables. One-way ANOVAs were used to test for differences in the total number of leaves and roots produced by seedlings between dead and live seedlings collected in May.

To examine the dynamics of the pool of reserves initially available for seedling growth, differences in $\mathrm{C}, \mathrm{N}$ and $\mathrm{P}$ concentrations in seeds from different sources (mature fruits versus $1 \mathrm{yr}$ live seedlings versus 1 to 2 yr live seedlings versus dead seedlings) were tested for significance using 1-way ANOVA followed by Tukey's post-hoc comparison tests.
Standard all-pair $t$-test comparisons $(\alpha=0.05)$ were used to determine whether mean $\mathrm{C}, \mathrm{N}$ or P concentrations in live seedlings differed statistically across the different tissue types (leaves, roots, rhizome and leaf scars). One-way ANOVAs were also performed to test for differences in the mean $\mathrm{C}, \mathrm{N}$ or $\mathrm{P}$ concentrations and atomic N/P and $\mathrm{C} / \mathrm{N}$ ratios in the seedling tissues between the sampling events. Finally, 1-way ANOVAs were performed to test for statistical differences in the $\mathrm{C}, \mathrm{N}$ and $\mathrm{P}$ concentrations and N/P and $\mathrm{C} / \mathrm{N}$ ratios in tissues between seedlings and rhizomes collected in December 2005. Variables were appropriately transformed when necessary to normalize data distributions and stabilize error term variances.

\section{RESULTS}

\section{Seed mass and nutrient content}

Seed mass ranged from 0.32 to $0.65 \mathrm{~g}$ dry wt (mean \pm $\mathrm{SD}=0.45 \pm 0.05 \mathrm{~g}$ dry $\mathrm{wt}$ ). The coefficient of variation in seed mass was $15.2 \%$. The distribution of seed masses (Fig. 2) tended to be skewed to the right and also exhibited positive kurtosis.

The mean $\mathrm{C}, \mathrm{N}$ and $\mathrm{P}$ concentrations were $36.13 \pm$ $0.16 \%, 1.49 \pm 0.05 \%$ and $0.13 \pm 0.003 \%$, respectively. The C, N and P content of seeds (Fig. 3) increased linearly with seed mass, as indicated by the slope $(b)$ of the regression functions fitted to log-transformed variables $(\mathrm{C}: b=1.01 \pm 0.03, \mathrm{~N}: b=0.80 \pm 0.21$ and $\mathrm{P}: b=$ $0.81 \pm 0.26)$. Most of the variation in the $C$ content of seeds was explained by seed mass $(97 \%)$. However, seed mass did not explain as well the total variance in the N (32\%) and P (24\%) content of seeds. The linear relationships between seed mass and seed content

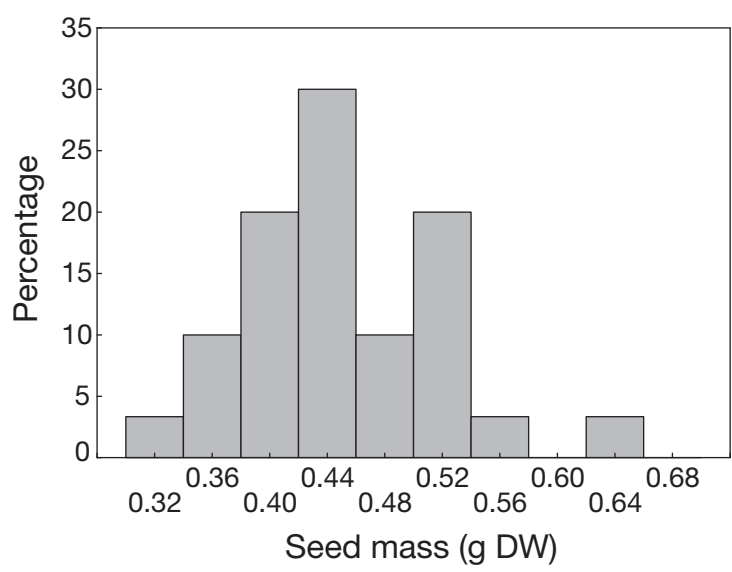

Fig. 2. Posidonia oceanica. Frequency distribution of seed mass (g dry wt) $(\mathrm{n}=30)$ 

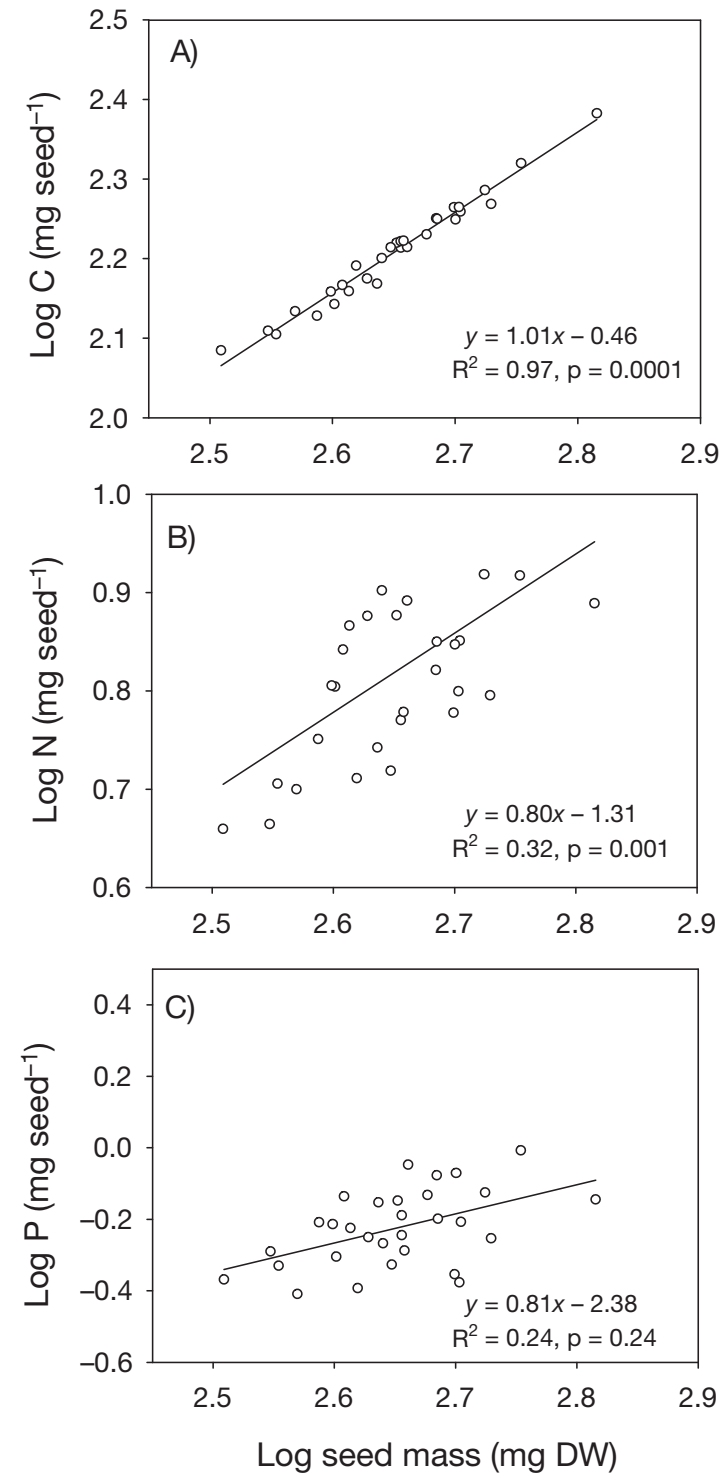

Fig. 3. Posidonia oceanica. Relationships between seed mass (mg dry wt) and the (A) C, (B) N and (C) P content (mg dry wt seed $^{-1}$ ) of seeds. Least-squares linear regression fitted to $\log _{10}$ transformed variables (solid lines). The coefficient of determination $\left(R^{2}\right)$ and the significance of the coefficient $(\mathrm{p})$ are provided $(n=30)$

indicated that the increase in seed content per unit of seed mass was relatively uniform across seeds.

\section{Seedling growth characteristics and tissue elemental analysis}

A seed still attached to the rhizome was present in $92 \%$ of the collected seedlings. The dry mass of seeds in the seedlings of May $2005(0.09 \pm 0.03 \mathrm{~g}$ dry wt) was about $1 / 4$ of the initial mass of seeds in fruits. Elemental concentration between seeds in fruits and seeds attached to seedlings are compared in Fig. 4. The average concentrations of $\mathrm{C}, \mathrm{N}$ and $\mathrm{P}$ in seeds declined significantly from mature fruits to $1 \mathrm{yr}$ old seedlings and did not change significantly between May and December $2005\left(\mathrm{C}: F_{2,6}=15.76, \mathrm{p}=0.004 ; \mathrm{N}: F_{2,6}=9.48, \mathrm{p}=\right.$ 0.01 ; $\left.\mathrm{P}: F_{2,6}=91.62, \mathrm{p}<0.0001\right)$. It was also true for the atomic N/P ratios $\left(F_{2,6}=6.40, \mathrm{p}=0.03\right.$; Fig. $\left.4 \mathrm{D}\right)$. No differences were observed between dead seedlings and live $1 \mathrm{yr}$ old seedlings $\left(\mathrm{C}: F_{1,4}=1.87, \mathrm{p}=0.24 ; \mathrm{N}: F_{1,4}=\right.$ $0.53, \mathrm{p}=0.83 ; \mathrm{P}: F_{1,4}=0.76, \mathrm{p}=0.43 ; \mathrm{N} / \mathrm{P}$ ratio: $F_{1,4}=$ $0.16, \mathrm{p}=0.70)$.

The biometry of seedlings was variable (Table 2). The seedlings consisted of one shoot, a very small rhizome (1 to $3.5 \mathrm{~cm}$ in length) with 2 to 5 adventitious roots. In May 2005 the number of standing leaves varied from 2 to 8 leaves (mean $\pm \mathrm{SD}=5.5 \pm 1.0$ leaves per seedling, $\mathrm{CV}=18.1 \%$ ) and the maximum leaf length was $13.1 \pm 1.7 \mathrm{~cm}(\mathrm{CV}=12.9 \%)$. The total seedling biomass was also variable, ranging from 0.19 to $0.73 \mathrm{~g}$ dry wt $\left(\right.$ mean $=0.45 \pm 0.13 \mathrm{~g}$ dry $\mathrm{wt}_{;} \mathrm{CV}=28.8 \%$ ). MANOVA showed significant differences in seedling development between the 2 sampling events $\left(F_{7,4}=\right.$ 11.55, $\mathrm{p}=0.001)$. Seedlings from May were collected 12 mo after germination (1 yr old seedlings) and were smaller in size compared with those collected in December, i.e. 19 mo after germination (1 to 2 yr old seedlings), exhibiting a lower number of leaf scars and a shorter rhizome (Table 2). However, the number of standing leaves and roots per seedling was similar, and leaves and roots were longer compared with those of December (Table 2). In total the number of leaves produced by seedlings from May was ca. 16, and this corresponded to the number of leaves produced by seedlings during the 1st year. The seedlings collected in December 2005 had produced ca. 23 leaves in total; thus, ca. 7 new leaves were produced between May and December 2005 of the 2 nd year. As the mean rate of annual leaf production was 16 leaves $\mathrm{yr}^{-1}$, on average a new leaf was produced by seedlings approximately every $25 \mathrm{~d}$. The seedlings collected in May categorized as dead seedlings did not show standing leaves and their rhizome were only a few millimetres in length: the number of leaf scars $(10 \pm 0.5)$ and roots $(3.5 \pm 0.5)$ per seedling was comparable with that of live seedlings collected in the same date $\left(F_{1,10}=0.55\right.$, $\left.\mathrm{p}=0.47 ; F_{1,10}=3.18, \mathrm{p}=0.10\right)$. Since dead seedlings had produced only 10 leaves in total, leaf production would be ceased several months before collection, possibly 7 to 8 mo after germination.

Elemental C, N and P concentrations and atomic N/P and $\mathrm{C} / \mathrm{N}$ ratios in seedlings from May and December 2005 are shown in Fig. 5. In terms of mean elemental concentrations in each tissue type, leaves were richer 

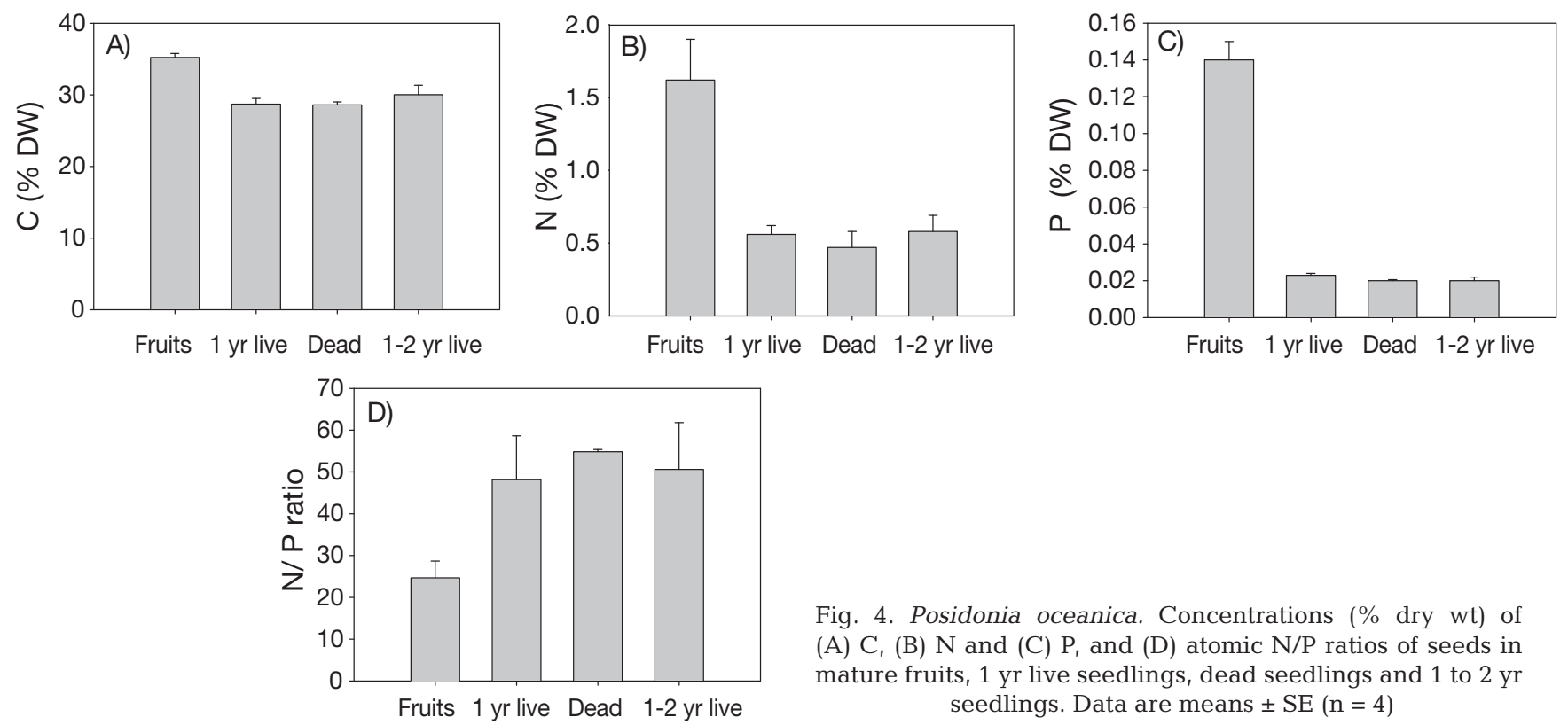

Fig. 4. Posidonia oceanica. Concentrations (\% dry wt) of (A) $\mathrm{C}$, (B) N and (C) P, and (D) atomic N/P ratios of seeds in mature fruits, 1 yr live seedlings, dead seedlings and 1 to 2 yr seedlings. Data are means \pm SE $(n=4)$

Table 2. Posidonia oceanica. Morphological measurements for $1 \mathrm{yr}$ and 1 to 2 yr live seedlings, and results of 1 -way ANOVA test ing for the effects of sampling event (May versus December 2005) on each morphological variable. Data are mean $\pm \mathrm{SE}, \mathrm{n}=6$

\begin{tabular}{|c|c|c|c|c|c|c|}
\hline \multirow[t]{2}{*}{ Dependent variable } & \multicolumn{2}{|c|}{ Mean $\pm \mathrm{SE}$} & \multirow[t]{2}{*}{ MS } & \multirow[t]{2}{*}{$F$} & \multirow[t]{2}{*}{$\mathrm{p}$} & \multirow[t]{2}{*}{ Transformation } \\
\hline & May & December & & & & \\
\hline Number of standing leaves & $5.5 \pm 1.0$ & $5.6 \pm 0.5$ & 0.08 & 0.01 & 0.89 & None \\
\hline Number of leaf scars & $10.5 \pm 0.4$ & $16.8 \pm 0.9$ & 120.23 & 37.21 & $<0.0001$ & None \\
\hline Length longest leaf (cm) & $13.1 \pm 1.7$ & $7.8 \pm 1.3$ & 85.73 & 5.91 & 0.03 & None \\
\hline Leaf width $(\mathrm{cm})$ & 0.50 & 0.51 & 12.26 & 45.54 & $<0.001$ & $\log (x)$ \\
\hline Number of roots & $4.6 \pm 0.3$ & $5.5 \pm 1.0$ & 0.02 & 0.16 & 0.69 & Square root $(x)$ \\
\hline Length longest root (cm) & $4.0 \pm 0.4$ & $2.3 \pm 0.5$ & 9.36 & 6.55 & 0.02 & None \\
\hline Rhizome length (cm) & $1.4 \pm 0.1$ & $3 \pm 0.4$ & 3.49 & 54.94 & $<0.001$ & $\log (x)$ \\
\hline
\end{tabular}

in $\mathrm{C}$ in May, whereas rhizomes and roots were richer in $\mathrm{C}$ in December. Leaves and rhizomes were always richer in $\mathrm{N}$, while rhizomes were richer in $\mathrm{P}$ (Fig. 5). In May the $\mathrm{C}$ concentration in leaves was significantly higher compared with that of December, while the concentrations of the other tissues were significantly lower (Fig. 5A, Table 3). The $\mathrm{N}$ and $\mathrm{P}$ concentrations in leaves, rhizome and scars in May were significantly higher than those in December, while root concentrations of $\mathrm{N}$ were not (Fig. 5B,C, Table 3). There were significant differences in the atomic $\mathrm{C} / \mathrm{N}$ ratio of all tissues between sampling events (Fig. 5E, Table 3). The atomic N/P ratio of scars was higher in December than in May, while the N/P values of the other tissues were comparable (Fig. 5D, Table 3).

Seedlings tended to have lower leaf $\mathrm{C}, \mathrm{N}$ and $\mathrm{P}$ and N/P leaf ratio concentrations than adult plants (Fig. 6A-D), although the differences were not statistically significant $\left(\mathrm{C}: F_{1,4}=0.56, \mathrm{p}=0.49 ; \mathrm{N}: F_{1,4}=6.10\right.$, $\mathrm{p}=0.06 ; \mathrm{P}: F_{1,4}=0.26, \mathrm{p}=0.63 ; \mathrm{N} / \mathrm{P} ; F_{1,4}=1,62, \mathrm{p}=$ $0.27)$. Roots and scars of adult plants were impoverished in $\mathrm{N}\left(F_{1,4}=16.61, \mathrm{p}=0.01\right.$ and $F_{1,4}=65.17, \mathrm{p}=$ 0.001, respectively) compared with seedlings, but had similar $\mathrm{P}\left(F_{1,4}=0.97, \mathrm{p}=0.37\right.$ and $\left.F_{1,4}=0.09, \mathrm{p}=0.76\right)$ and $\mathrm{C}$ values $\left(F_{1,4}=1.64, \mathrm{p}=0.06\right.$ and $F_{1,4}=0.001, \mathrm{p}=$ 0.97). Rhizomes of adult plants were impoverished in $\mathrm{C}$ $\left(F_{1,4}=109.26, \mathrm{p}=0.0004\right)$, but their $\mathrm{N}\left(F_{1,4}=1.31, \mathrm{p}=\right.$ $0.31)$ and $\mathrm{P}\left(F_{1,4}=0.15, \mathrm{p}=0.71\right)$ concentration was comparable with those of seedlings (Fig. 6A-D). The $\mathrm{C} / \mathrm{N}$ ratio of leaves of adult plants was lower $\left(F_{1,4}=\right.$ 8.03, $\mathrm{p}=0.04$ ) than that of seedlings, while no significant differences were detected for the other tissues (roots: $F_{1,4}=3.18, \mathrm{p}=0.14 ;$ scars: $F_{1,4}=1.75, \mathrm{p}=0.25$; rhizome: $F_{1,4}=1.89, \mathrm{p}=0.24$; Fig. $\left.6 \mathrm{E}\right)$. Finally, no significant differences were detected for tissue $\mathrm{C}$ or $\mathrm{P}$ concentrations between dead and live seedlings, while the $\mathrm{N}$ concentrations were lower in dead seedlings than in live seedlings (Table 4). 

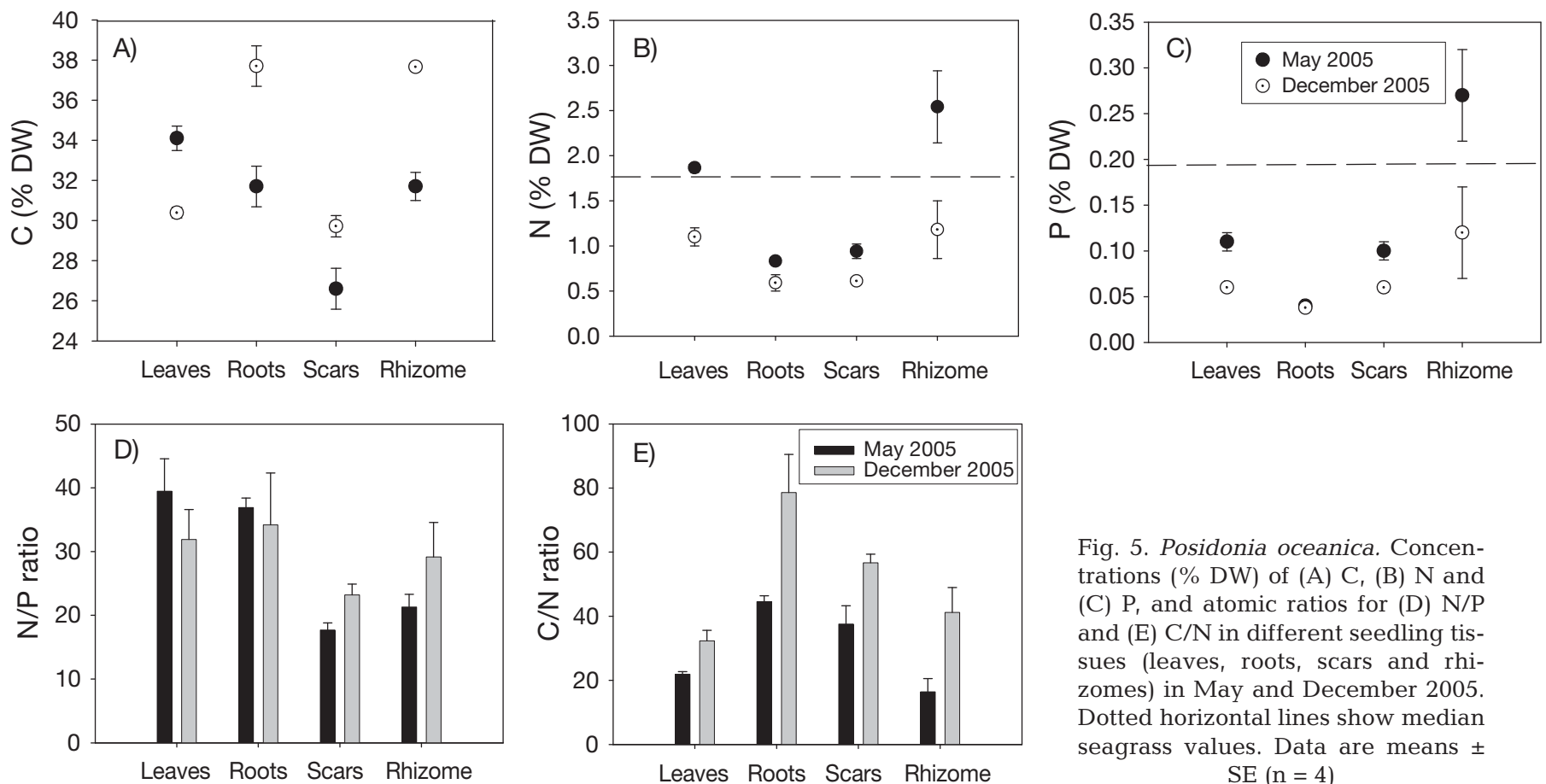

Fig. 5. Posidonia oceanica. Concentrations (\% DW) of (A) $\mathrm{C}_{\text {, }}$ (B) $\mathrm{N}$ and (C) $\mathrm{P}$, and atomic ratios for (D) N/P and (E) $\mathrm{C} / \mathrm{N}$ in different seedling tissues (leaves, roots, scars and rhizomes) in May and December 2005. Dotted horizontal lines show median seagrass values. Data are means \pm $\mathrm{SE}(\mathrm{n}=4)$

Table 3. Posidonia oceanica. Results of 1-way ANOVAs testing for the effects of sampling event (May versus December) on the $\mathrm{C}, \mathrm{N}$ and $\mathrm{P}$ concentrations, and $\mathrm{C} / \mathrm{N}$ and atomic N/P ratios for each tissue type (leaves, leaf scars, rhizome and roots) of live seedlings. Results of Tukey's tests are also reported where values differ significantly. ns: not significant; $\mathrm{n}=4$

\begin{tabular}{|c|c|c|c|c|c|c|}
\hline $\begin{array}{l}\text { Dependent } \\
\text { variable }\end{array}$ & Tissue type & MS & $F$ & $\mathrm{p}$ & Transformation & Tukey's test \\
\hline $\mathrm{C}$ & $\begin{array}{l}\text { Scars } \\
\text { Rhizome } \\
\text { Leaves } \\
\text { Roots }\end{array}$ & $\begin{array}{l}34.76 \\
71.21 \\
34.19 \\
58.51\end{array}$ & $\begin{array}{l}34.31 \\
64.51 \\
40.57 \\
13.26\end{array}$ & $\begin{array}{l}0.001 \\
0.0002 \\
0.0007 \\
0.01\end{array}$ & $\begin{array}{l}\text { None } \\
\text { None } \\
\text { None } \\
\text { None }\end{array}$ & $\begin{array}{l}\text { December }>\text { May } \\
\text { December }>\text { May } \\
\text { May }>\text { December } \\
\text { December }>\text { May }\end{array}$ \\
\hline $\mathrm{N}$ & $\begin{array}{l}\text { Scars } \\
\text { Rhizome } \\
\text { Leaves } \\
\text { Roots }\end{array}$ & $\begin{array}{l}0.22 \\
3.64 \\
1.11 \\
0.11\end{array}$ & $\begin{array}{r}15.95 \\
8.32 \\
38.29 \\
4.77\end{array}$ & $\begin{array}{l}0.007 \\
0.02 \\
0.000 \\
0.07\end{array}$ & $\begin{array}{l}\text { None } \\
\text { None } \\
\text { None } \\
\text { None }\end{array}$ & $\begin{array}{l}\text { May > December } \\
\text { May > Decembe } \\
\text { May > December }\end{array}$ \\
\hline $\mathrm{P}$ & $\begin{array}{l}\text { Scars } \\
\text { Rhizome } \\
\text { Leaves } \\
\text { Roots }\end{array}$ & $\begin{array}{r}0.007 \\
0.057 \\
0.004 \\
0.00018\end{array}$ & $\begin{array}{r}13.84 \\
7.13 \\
7.17 \\
5.55\end{array}$ & $\begin{array}{l}0.009 \\
0.039 \\
0.03 \\
0.056\end{array}$ & $\begin{array}{l}\text { None } \\
\text { None } \\
\text { None } \\
\text { None }\end{array}$ & $\begin{array}{c}\text { May }>\text { December } \\
\text { May }>\text { Decembe } \\
\text { May }>\text { Decembe } \\
\text { ns }\end{array}$ \\
\hline $\mathrm{C} / \mathrm{N}$ ratio & $\begin{array}{l}\text { Scars } \\
\text { Rhizome } \\
\text { Leaves } \\
\text { Roots }\end{array}$ & $\begin{array}{r}1196.21 \\
1223.45 \\
0.296 \\
0.56\end{array}$ & $\begin{array}{r}52.38 \\
7.64 \\
14.32 \\
10.11\end{array}$ & $\begin{array}{l}0.003 \\
0.03 \\
0.009 \\
0.01\end{array}$ & $\begin{array}{l}\text { None } \\
\text { None } \\
\log (x) \\
\log (x)\end{array}$ & $\begin{array}{l}\text { December }>\text { May } \\
\text { December }>\text { May } \\
\text { December }>\text { May } \\
\text { December }>\text { May }\end{array}$ \\
\hline N/P ratio & $\begin{array}{l}\text { Scars } \\
\text { Rhizome } \\
\text { Leaves } \\
\text { Roots }\end{array}$ & $\begin{array}{r}61.89 \\
120.59 \\
114.76 \\
14.76\end{array}$ & $\begin{array}{l}7.46 \\
1.77 \\
1.17 \\
0.107\end{array}$ & $\begin{array}{l}0.03 \\
0.23 \\
0.32 \\
0.75\end{array}$ & $\begin{array}{l}\text { None } \\
\text { None } \\
\text { None } \\
\text { None }\end{array}$ & $\begin{array}{c}\text { December }>\text { May } \\
\text { ns } \\
\text { ns } \\
\text { ns }\end{array}$ \\
\hline
\end{tabular}

\section{DISCUSSION}

One of the basic features that contribute to the continued success of a species in a nutrient-poor environment is the capacity on the part of seeds to sequester and concentrate a considerable proportion of the plant's resource of the limiting nutrients (Pate \& Dell 1984). Australian seagrasses belonging to the Posidoniacae (Posidonia australis Hook f., P. sinuosa Cambridge and Kuo and $P$. coriacea Kuo and Cambridge) are likely to 

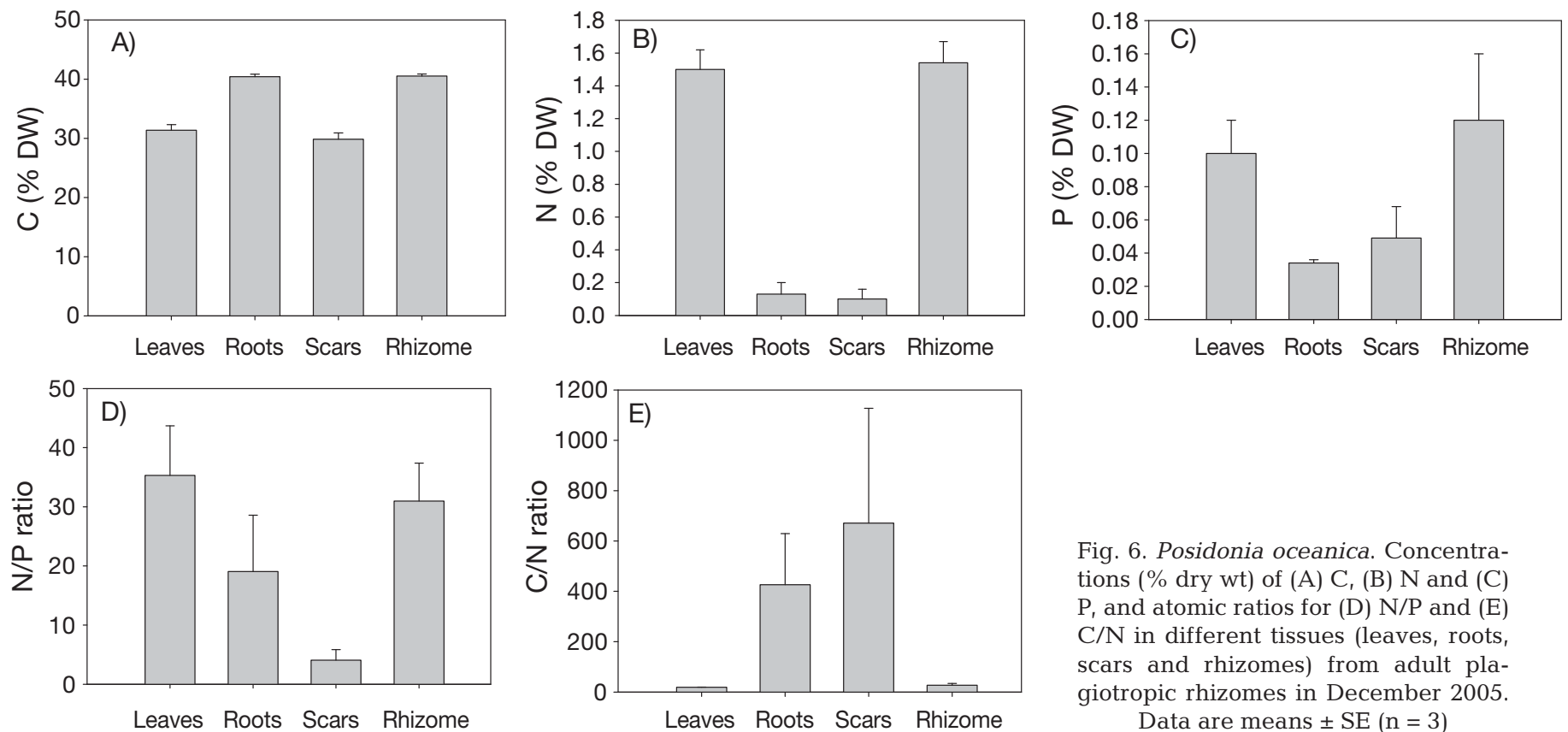

Fig. 6. Posidonia oceanica. Concentrations (\% dry wt) of (A) $\mathrm{C}$, (B) N and (C) $\mathrm{P}$, and atomic ratios for (D) N/P and (E) $\mathrm{C} / \mathrm{N}$ in different tissues (leaves, roots, scars and rhizomes) from adult plagiotropic rhizomes in December 2005. Data are means \pm SE $(n=3)$

Table 4. Posidonia oceanica. Results of 1-way ANOVAs testing for the effects of seedling status (dead versus live) on the C, N and P concentrations for each tissues type (leaf scars and roots) of seedlings (May 2005). Results of Tukey's tests are also reported where values differ significantly. Values in round brackets indicate mean $( \pm \mathrm{SE})$ concentrations of the elements in each tissue type. $\mathrm{n}=10$

\begin{tabular}{|c|c|c|c|c|c|c|}
\hline $\begin{array}{l}\text { Dependent } \\
\text { variable }\end{array}$ & Tissue type & MS & $F$ & $\mathrm{p}$ & Concentration & Tukey's test \\
\hline \multirow[t]{2}{*}{$\mathrm{C}$} & Roots & 0.050 & 0.022 & 0.88 & $\begin{array}{l}\text { Dead }(32.73 \pm 0.68 \%) \\
\text { Alive }(32.86 \pm 0.59 \%)\end{array}$ & \\
\hline & Scars & 2.13 & 3.96 & 0.16 & $\begin{array}{l}\text { Dead }(25.61 \pm 0.45 \%) \\
\text { Alive }(26.50 \pm 0.40 \%\end{array}$ & \\
\hline \multirow[t]{2}{*}{$\mathrm{N}$} & Roots & 0.821 & 77.40 & 0.000 & $\begin{array}{l}\text { Dead }(0.43 \pm 0.04 \%) \\
\text { Alive }(0.84 \pm 0.02 \%)\end{array}$ & Dead $<$ Live \\
\hline & Scars & 5.94 & 1.03 & 0.025 & $\begin{array}{l}\text { Dead }(0.72 \pm 0.15 \%) \\
\text { Alive }(1.16 \pm 0.10 \%)\end{array}$ & Dead $<$ Live \\
\hline \multirow[t]{2}{*}{$\mathrm{P}$} & Roots & 0.0002 & 2.46 & 0.13 & $\begin{array}{l}\text { Dead }(0.04 \pm 0.003 \%) \\
\text { Alive }(0.05 \pm 0.001 \%)\end{array}$ & \\
\hline & Scars & 0.005 & 2.83 & 0.11 & $\begin{array}{l}\text { Dead }(0.16 \pm 0.01 \%) \\
\text { Alive }(0.13 \pm 0.005 \%)\end{array}$ & \\
\hline
\end{tabular}

invest a substantial amount of $\mathrm{P}$ and $\mathrm{N}$ into the seed reserves to provide newly established seedlings with nutrients for several months after germination (Hocking et al. 1980, Tomlinson 1982, Kuo \& Kirkman 1996, Walker et al. 2004). The present study demonstrates that the seeds of $P$. oceanica had, on average, higher $N$ concentration (1.6\% versus 0.7 to $1.3 \%$ ) but lower P concentration $(0.14 \%$ versus 0.18 to $0.36 \%)$ compared with the Australian Posidonia species. Instead, compared with other Mediterranean seagrasses such as Cymodocea nodosa, the N seed concentration was lower $(1.6 \%$ versus $2.3 \%)$ and $\mathrm{P}$ was equivalent $(0.14 \%$ versus
$0.13 \%$, Duarte \& Sand-Jensen 1996). In terms of absolute quantity of nutrients, however, the seeds of $P$. oceanica contained ca. $6.78 \mathrm{mg}$ of $\mathrm{N}$ and $0.63 \mathrm{mg}$ of $\mathrm{P}$, whereas this amount reached only ca. $2.80 \mathrm{mg}$ of $\mathrm{N}$ and $0.47 \mathrm{mg}$ of $\mathrm{P}$ in P. australis seeds (Hocking et al. 1980) and ca. $0.32 \mathrm{mg}$ of $\mathrm{N}$ and $0.02 \mathrm{mg}$ of $\mathrm{P}$ in C. nodosa (Duarte \& Sand-Jensen 1996). The ability of $P$. oceanica to produce such nutrient-rich seeds may be a strategy to allow prolonged seedling development in environments where nutrients are in concentrations low enough to limit the establishment of other species such as C. nodosa (Pérez et al. 1991, 1994). 
This study also documents substantial variation in the mass of seeds produced by Posidonia oceanica within the study population, which is consistent with degree of variation reported for some terrestrial plants $(\mathrm{CV}=13.6$ to $23.6 \%$, Obeso 1993, Susko \& LovettDoust 2000). The C, N and P content of seeds increased linearly with seed mass, indicating that the availability of these elements may constrain seed provisioning and impose a cost on producing larger seeds in terms of limited environmental nutrients. Since flowering in $P$. oceanica requires a considerable demand on reserves of useable nutrients, especially $\mathrm{N}$ and $\mathrm{P}$ (Gobert et al. 2005), the production of seeds of variable masses could be related to within-meadow differences in the resource available to reproductive shoots, or development constraints operating during fruit maturation within individual shoots. Further studies are needed to asses whether seeds of $P$. oceanica below a certain mass have enough reserves to protect seedlings from nutrient stress during the 1st year of establishment.

The analysis of the nutrient and $\mathrm{C}$ content of Posidonia oceanica seeds in mature fruits and in seeds remained attached to dead seedlings indicates that the $\mathrm{N}$ and $\mathrm{P}$ reserves were retrieved from the hypocotyl to the seedling axis within 7 to 8 mo after germination, with 69 and $86 \%$ efficiency, respectively, assuming no losses due to leaching, while only $20 \%$ of the C reserves were used. As the seed nutrient concentrations in live seedlings were similar to those of dead ones and did not change significantly with age, the reserves that remained uncommitted were incorporated in structural tissues of the seed, rather than contributing to seedling growth. Morphological examination of live seedlings revealed that ca. 7 leaves were produced between May and December of the 2nd yr; thus, the nutrient requirements for the production of new biomass would have been met by active uptake of external nutrient supplies and reallocation of existing material.

The uptake of nutrients by leaves and their storage within different plant components (rhizomes, in particular) in autumn through winter and remobilization in spring through summer is an important strategy adopted by Posidonia oceanica to obtain independence from seasonal variations in nutrients in the environment (Alcoverro et al. 1997, 2000, Lepoint et al. 2002). Results presented here indicate that the distribution of nutrients within seedling tissues was comparable with the pattern reported for adult plants (Alcoverro et al. 2000, Invers et al. 2002, Lepoint et al. 2002), with high values of $\mathrm{P}$ and $\mathrm{N}$ in rhizomes and minimum values in roots. The decrease in the nutrient tissue concentrations observed between May and December may indicate that in this period the nutrient demands for active leaf growth exceed uptake, and part of this demand was met by the reserves accumulated in excess of growth demands during the previous winter. The concomitant increase in the $\mathrm{C}$ concentration in rhizomes and roots indicates storage of the carbon taken up in excess in summer, in accordance with that found in adult plants (Alcoverro et al. 2001). It appears, therefore, that the rhizome contributes significantly to the nutrient economy of seedlings during the 1st year, while the contribution of roots appeared to be limited.

Analysis of the leaf nutrient content of seedlings shows that in May the P concentration was below the median values characteristics of nutrient-deficient plants reported for seagrasses $(0.2 \%)$, while the $\mathrm{N}$ concentration was close to the median values for seagrasses (1.8\%, Duarte 1990). In December both P and $\mathrm{N}$ concentrations were below the median values reported for seagrasses (Duarte 1990), and were also lower compared with apical shoots in plagiotropic rhizomes although the differences were not statistically significant. The leaf N/P ratio decreased from 39 (May) to 31 (December) as a result of decrease in $\mathrm{N}$ and little variation in $\mathrm{P}$, and these values were in the range considered to be P-limited (30 to 40, Duarte 1990).

In summary, the results of this study indicate that Posidonia oceanica produce large seeds containing more mineral nutrients ( $\mathrm{N}$ and $\mathrm{P}$ ) compared with some closely related species. It seems that during the early seedling developmental phase the seeds act to supplement environmental supplies of $\mathrm{N}$ and $\mathrm{P}$ to ensure rapid growth of shoot and roots. Resource constraints, however, may affect the nutritional quality of seeds with potential important consequences for seedling performance. Seedlings appeared to be primarily limited by $\mathrm{P}$ during their second growing season. This lends support to the hypothesis that growth limitation due to nutrient deficiency may be a cause of mortality for seedlings established on poor-nutrient patches. These findings may have important implications for the restoration of $P$. oceanica meadows, as the use of adequate fertilization practices is expected to enhance the success of future seedling transplantation programs. Clearly, determination of the nutrient content in uprooted seedlings cannot be the only criterion for the assessment of the extent of nutrient deficiency experienced by seedlings of $P$. oceanica. Further longterm studies and experimental tests on nutrient addition or the uptake of nutrients and other essential elements in seedlings growing in the field are needed.

Acknowledgements. The authors are grateful for the technical assistance of Renzo Biondo. The study was funded by the Department of Biology, University of Pisa, Italy (308ex60\%2006), and FRS-FNRS (2.4502.08), the French community of Belgium (ARC Race 05/10/333). This publication has the MARE publication number MARE170. 


\section{LITERATURE CITED}

Ågren J (1989) Seed size and number in Rubus chamaemorus: between-habitat variation, and effects of defoliation and supplemental pollination. J Ecol 77:1080-1092

Alberto F, Correira L, Arnaud-Haond S, Billot C, Duarte CM, Serrão E (2003) New microsatellite markers for the endemic Mediterranean seagrass Posidonia oceanica. Mol Ecol Notes 3:253-255

Alcoverro T, Duarte CM, Romero J (1995) Annual growth dynamics of Posidona oceanica: contribution of large-scale versus local factors to seasonality. Mar Ecol Prog Ser 120: 203-210

- Alcoverro T, Romero J, Duarte CM, López NI (1997) Spatial and temporal variations in nutrient limitation of seagrass Posidonia oceanica growth in the NW Mediterranean. Mar Ecol Prog Ser 146:155-161

Alcoverro T, Manzanera M, Romero J (2000) Nutrient mass balance of the seagrass Posidonia oceanica: the importance of nutrient retranslocation. Mar Ecol Prog Ser 194: $13-21$

Alcoverro T, Manzanera M, Romero J (2001) Annual metabolic carbon balance of the seagrass Posidonia oceanica: the importance of carbohydrate reserves. Mar Ecol Prog Ser 211:105-116

Balestri E (2004) Flowering of the seagrass Posidonia oceanica in a north-western Mediterranean coastal area: temporal and spatial variations. Mar Biol 145:61-68

Balestri E, Bertini S (2003) Growth and development of Posidonia oceanica treated with plant growth regulators: possible implications for meadow restoration. Aquat Bot 76: 291-297

Balestri E, Cinelli F (2003) Sexual reproductive success in Posidonia oceanica. Aquat Bot 75:21-32

Balestri E, Lardicci C (2008) First evidence of a massive recruitment event in Posidonia oceanica: spatial variation in first-year seedling abundance on a heterogeneous substrate. Estuar Coast Shelf Sci 76:634-641

Balestri E, Piazzi L, Cinelli F (1998a) Survival and growth of transplanted and natural seedlings of Posidonia oceanica (L.) Delile in a damaged coastal area. J Exp Mar Biol Ecol 228:209-225

Balestri E, Piazzi L, Cinelli F (1998b) In vitro germination and seedling development of Posidonia oceanica. Aquat Bot 60:83-93

Balestri E, Vallerini F, Lardicci C (2006) A qualitative and quantitative assessment of the reproductive litter from Posidonia oceanica accumulated on a sand beach following a storm. Estuar Coast Shelf Sci 66:30-34

Ballesteros E (1989) Production of seaweeds in Northwestern Mediterranean marine communities: its relation with environmental factors. Sci Mar 53:357-364

Belzunce M, Navarro RM, Rapoport HF (2005) Seed and early plantlet structure of the Mediterranean seagrass Posidonia oceanica. Aquat Bot 82:269-283

Bonfil C (1998) The effects of seed size, cotyledon reserves, and herbivory on seedling survival and growth in Quercus rugosa and Q. Laurina (Fagaceae). Am J Bot 85:79-87

Buia MC, Mazzella L (1991) Reproductive phenology of the Mediterranean seagrasses Posidonia oceanica (L.) Delile, Cymodocea nodosa (Ucria) Aschers., and Zostera nolti Hornem. Aquat Bot 40:343-362

Diaz-Almela E, Marbà N, Álvarez E, Balestri E, Ruiz-Fernãndez JM, Duarte CM (2006) Pattern in seagrass (Posidonia oceanica) flowering in the Western Mediterranean. Mar Biol 148:723-742

Diaz Almela E, Marbà N, Álvarez E, Santiago R, Martínez R
(2008) Patch dynamics of the Mediterranean seagrass Posidonia oceanica: implications for recolonization process. Aquat Bot 89:397-403

Duarte CM (1990) Seagrass nutrient content. Mar Ecol Prog Ser 67:201-207

Duarte CM, Sand-Jensen K (1990) Seagrass colonization: patch formation and patch growth in Cymodocea nodosa. Mar Ecol Prog Ser 65:193-200

> Duarte CM, Sand-Jensen K (1996) Nutrient constraints on establishment from seed and on vegetative expansion of the Mediterranean seagrass Cymodocea nodosa. Aquat Bot 54:279-286

$>$ Foster SA (1986) On the adaptive value of large seeds for tropical moist forest trees: a review and synthesis. Bot Rev 52:260-299

Gobert S, Lejeune P, Lepoint G, Bouquegneau JM (2005) C, N, P concentrations and requirements of flowering Posidonia oceanica shoots. Hydrobiologia 533:253-259

Hocking PJ, Cambridge ML, McComb AJ (1980) Nutrient accumulation in the fruits of two species of seagrass, Posidonia australis and Posidonia sinuosa. Ann Bot 45: $149-161$

- Hootsmans MJM, Vermaat JE, van Vierssen W (1987) Seedbank development, germination and early seedling survival of two seagrass species from The Netherlands: Zostera marina L. and Zostera noltii Hornem. Aquat Bot 28:275-285

> Houssard C, Escarré J (1991) The effects of seed weight on growth and competitive ability of Rumex acetosella from two successional old-fields. Oecologia 86:236-242

Invers O, Pérez M, Romero J (2002) Seasonal nitrogen speciation in temperate seagrass Posidonia oceanica (L.) Delile. J Exp Mar Biol Ecol 273:219-240

Jover MA, Del Castillo-Agudo L, Garcia-Carrascosa M, Segua J (2003) Random amplified polymorphic assessment of diversity in western Mediterranean populations of the seagrass Posidonia oceanica. Am J Bot 90:364-369

- Krannitz PG (1997) Variation in magnesium and nitrogen content in seeds of antelope bitterbrush (Purshia tridentata, Rosaceae). Am J Bot 84:1738-1742

Kuo J, Kirkman H (1996) Seedling development of selected Posidonia species from southwest Australia. In: Kuo J, Phillips RC, Walker D, Kirkman H (eds) Seagrass biology: proceedings of an international workshop. Rotnest Island, Western Australia, p 57-64

Lepoint G, Millet S, Dauby P, Gobert S, Bouquegneau JM (2002) Annual nitrogen budget of the seagrass Posidonia oceanica as determined by in situ uptake experiments. Mar Ecol Prog Ser 237:87-96

Lord JM (1994) Variation in Festuca novae-zelandiae (Hack.) Cockayne germination behaviour with latitude of seed source. NZ J Bot 32:227-235

Matthies D (1990) Plasticity of reproductive components at different stages of development in the annual plant Thalaspi arvense L. Oecologia 83:105-116

Mazer J (1989) Ecological, taxonomic and life history correlates of seed mass among Indiana dune angiosperms. Ecol Monogr 59:153-175

McKee J, Richards AJ (1996) Variation in seed production and germinability in common reed (Phragmites australis) in Britain and France with respect to climate. New Phytol 133:233-243

Mehlman DW (1993) Seed size and seed packaging variation in Baptisia lanceolata (Fabaceae). Am J Bot 80:735-742

Migliaccio M, Di Martino F, Silvestre F, Procaccini G (2005) Meadow-scale genetic structure in Posidonia oceanica. Mar Ecol Prog Ser 304:55-65 
Milberg P, Lamont BB (1997) Seed/cotyledon size and nutrient content play a major role in early performance of species on nutrient-poor soils. New Phytol 137:665-672

Naegle ER, Burton JW, Carter TE, Rufty TW (2005) Influence of seed nitrogen content on seedling growth and recovery from nitrogen stress. Plant Soil 271:329-340

$>$ Navarro L (1996) Fruit-set and seed weight variation in Anthyllis vulneraria subsp. vulgaris (Fabaceae). Plant Syst Evol 201:139-148

Nielsen S, Pedersen MF (2000) Growth, photosynthesis and nutrient content of seedlings and mature plants of Cymodocea nodosa - the importance of clonal integration. Aquat Bot 68:265-271

Obeso JR (1993) Seed mass variation in the perennial herb Asphodelus albus: sources of variation and position effect. Oecologia 93:571-575

Olesen B, Sand-Jensen K (1994) Demography of shallow eelgrass (Zostera marina) populations - shoot dynamics and biomass development. J Ecol 82:379-390

Pate JS, Dell B (1984) Economy of mineral nutrients in sandplain species. In: Pate JS, Beard JS (eds) Kwongan: plant life of the sandplain. University of Western Australia Press, Nedlands, p 227-252

Pérez M, Romero J, Duarte CM, Sand-Jensen K (1991) Phosphorus limitation of Cymodocea nodosa growth. Mar Biol 109:129-133

Pérez M, Duarte CM, Romero J, Sand-Jensen K, Alcoverro T (1994) Growth plasticity in Cymodocea nodosa stands: the importance of nutrient supply. Aquat Bot 47:249-264

Piazzi L, Acunto S, Cinelli F (1999) In situ survival and development of Posidonia oceanica (L.) Delile seedlings. Aquat Bot 63:103-112

Robertson AJ, Mann KH (1984) Disturbance by ice and life history adaptations of the seagrass Zostera marina. Mar Biol 80:131-141

Editorial responsibility: Hans Heinrich Janssen, Oldendorf/Luhe, Germany
Seiwa K, Kikuzawa K (1991) Phenology of tree seedlings in relation to seed size. Can J Bot 69:532-538

Si.Di.Mar. (Sistema Difesa Mare) (2005). Programma per il monitoraggio per il controllo degli ambienti marinocostieri. Ministero dell'Ambiente e Tutela del Territorio. www.sidimar.tutelamare.it

Simons AM, Johnston MO (2000) Variation in seed traits of Lobelia inflate (Campanulaceae): sources and fitness consequences. Am J Bot 87:124-132

Susko DJ, Lovett-Doust L (2000) Patterns of seed mass variation and their effects on seedling traits in Alliara petiolata (Brassicaceae). Am J Bot 87:56-66

> Terrados J (1993) Sexual reproduction and seed banks of Cymodocea nodosa (Ucria) Aschers. Meadows on the southeast Mediterranean coast of Spain. Aquat Bot 46: 293-299

Tomlinson PB (1982) Anatomy of the monocotyledons VII. Helobiae (Alismatidae). Claredon Press, Oxford

Tyler G, Zohlen A (1998) Plant seeds as nutrient resources for seedlings - a comparison of plants from calcareous and silicate soils. Ann Bot 81:455-459

Vaughton G, Ramsey M (1998) Sources and consequences of seed mass variation in Banksia marginata (Proteaceae). J Ecol 86:563-573

Vaughton G, Ramsey M (2001) Relationships between seed mass, seed nutrients, and seedling growth in Banksia cunnighamii (Protaceae). Int J Plant Sci 162:599-606

Vidondo B, Duarte CM (1995) Seasonal growth of Codium bursa, a slow-growing Mediterranean macroalga: in situ evidence of nutrient limitation. Mar Ecol Prog Ser 123: 185-191

> Walker DI, Campey ML, Kendrick GA (2004) Nutrient dynamics in two seagrass species, Posidonia coriacea and Zostera tasmanica, on Success Bank, Western Australia. Estuar Coast Shelf Sci 60:251-260

Submitted: March 26, 2009; Accepted: May 11, 2009

Proofs received from author(s): July 23, 2009 